\title{
Investigation of Mortars and Plasters of a Byzantine Church in Southwest Anatolia with Emphasis on Possible Pozzolan Use
}

\author{
Evin CANER ${ }^{1}$, Bilge Alp GÜNEY ${ }^{2}$ * \\ ${ }^{1}$ Department of Conservation and Restoration of Cultural Heritage, Pamukkale University, 20070 Denizli, Turkey \\ ${ }^{2}$ Department of Architecture, Middle East Technical University, 06800 Ankara, Turkey \\ crossref http://dx.doi.org/10.5755/j01.ms.24.3.18590
}

Received 14 July 2017; accepted 06 October 2017

\begin{abstract}
Characterization of mortars and plasters used in historical structures is crucial before conservation interventions in order to propose proper repair materials and avoid any damage caused by material incompatibility. In the present study, mortars and plasters of a Byzantine Church in the ancient city of Stratonikeia dated back to $5^{\text {th }}-7^{\text {th }}$ centuries were examined in terms of physical/physico-mechanical characteristics and raw materials used by various analytical techniques. Possible use of pozzolanic materials in mortar and plaster samples were investigated by pozzolanic activity tests performed on the aggregates $(<125 \mu \mathrm{m})$ and examining the reaction products formed after immersion of these aggregates in a saturated solution of $\mathrm{Ca}(\mathrm{OH})_{2}$. Investigated mortar and plaster samples were found to have relatively low bulk density and high effective porosity. Compressive strength values of mortar samples were found to be in the range of $3.92-4.47 \mathrm{MPa}$. Binder used in the mortar and plaster samples were assessed to be fat lime. Aggregates of the samples smaller than $125 \mu \mathrm{m}$ were found to have good pozzolanicity. Formation of pozzolanic reaction products by the reaction of the finer aggregates with $\mathrm{Ca}(\mathrm{OH})_{2}$ were confirmed by the results of SEM-EDX and FTIR analyses.

Keywords: lime mortar, lime plaster, pozzolan, Stratonikeia.
\end{abstract}

\section{INTRODUCTION}

Historical mortars and plasters are composite materials containing binders with varying properties and aggregates which can be inert or reactive with regards to the binder, the latter of which having the ability to react with the binder and alter the final characteristics [1]. The composition and characteristics of mortars and plasters vary to a great extend depending on the construction period, location and expected function in the building.

Characterization of historical mortars and plasters has vital importance in order to understand the technology, production techniques and raw ingredients of these composite materials belonging to a particular structure built in a certain period. As the adverse effects and irreversible damage related to incompatible material use for the repair works of historic buildings disregarding the characteristics of original building materials are well documented in literature [2,3], the information gathered by the characterization studies is also essential to serve as a basis for the development and proposal of compatible repair materials to be used in the intervention works [4-7]. This is especially the case for composite materials such as mortars and plasters since the raw materials, production techniques and mixing proportions used directly affect the characteristics of the final composite.

In this study, basic physical, physico-mechanical and raw materials characteristics of mortar and plaster samples from a Byzantine Church dated back to $5^{\text {th }}-7^{\text {th }}$ centuries [8] located in the ancient city of Stratonikeia are examined. The city, which now resides in the district of Muğla (Turkey), has a history reaching back to Bronze Age and

\footnotetext{
* Corresponding author. Tel.: +90-312-2106238; fax: +90-312-2107966 E-mail address: bguney@metu.edu.tr (B.A. Güney)
}

has been continuously inhabited throughout the periods of Archaic, Classical, Hellenistic, Roman, Byzantine, Principalities and Ottoman up until today [9].

\section{EXPERIMENTAL}

Mortar samples were taken from the west wall of the narthex, south wall of the central nave and under tesserae in the central nave and plaster samples were collected from the west wall of the narthex, which belong parts of the church still partially standing in the ancient city. Sample locations and nomenclature are given in Table 1.

Cross sections of mortar and plaster samples were initially examined under a stereo microscope (Leica Z16) for their visual characteristics such as the color of the binder and the color and shape of the aggregates. Cohesion of the samples were evaluated according to the recommendation NORMAL 12/83 issued by Italian CNR and ICR [10]. Basic physical characterization of the samples was performed by determining bulk density and effective porosity according to standard gravimetric test method [11]. Modulus of elasticity $(E)$ of the samples were evaluated indirectly by using bulk density values and the results of ultrasonic pulse velocity measurements (PUNDIT Plus Ultrasonic test equipment using $220 \mathrm{kHz}$ probes) [12]. Uniaxial compressive strength (UCS) of the samples was estimated by point load strength tests using an ELE Point Load Test Apparatus [13, 14].

Ratios of acid soluble and insoluble parts were determined by treating samples with dilute hydrochloric acid solution (5\%) and weighing the acid insoluble parts and evaluating the results. The granulometric analysis of the acid insoluble parts were performed by using sieves with mesh sizes of 4000, 2000, 1000, 500, 250, $125 \mu \mathrm{m}$. 
Table 1. Nomenclature and locations of the samples

\begin{tabular}{|c|c|c|}
\hline Sample & Description & Location \\
\hline SP1 & Plaster & West wall of narthex \\
\hline SP2 & Plaster & West wall of narthex \\
\hline SM1 & Mortar (masonry) & West wall of narthex \\
\hline SM2 & Mortar (masonry) & North wall of central nave \\
\hline SM3 & Mortar (masonry) & South wall of central nave \\
\hline SM4 & Mortar (tesserae) & East side of central nave \\
\hline
\end{tabular}

Mineralogical phases in mortar and plaster samples were determined by X-Ray powder diffraction spectrometry (XRPD) (Bruker D8 Advance Diffractometer with Sol-X detector). Microstructural and elemental analyses were performed by using a Scanning Electron Microscope (SEM) (Tescan Vega II XMU) coupled with Energy Dispersive X-ray Spectrometer (EDX) (Oxford Instruments $\mathrm{x}$-act).

Aggregates with sizes smaller than $125 \mu \mathrm{m}$ were investigated for their possible pozzolanic characteristics by measuring the difference in electrical conductivity $(\mathrm{mS} / \mathrm{cm})$ of the saturated $\mathrm{Ca}(\mathrm{OH})_{2}$ solution before and after immersion of the aggregates into the solution [15]. Furthermore, in order to investigate the possible reaction products between the aggregates $(<125 \mu \mathrm{m})$ and lime, aggregates were left in a saturated solution of $\mathrm{Ca}(\mathrm{OH})_{2}$ for 7 days in airtight containers, then washed thoroughly with distilled water and examined by SEM-EDX and FTIR analysis (Bruker Alpha T with ATR attachment).

\section{RESULTS AND DISCUSSION}

The colors of the binder matrix for the plaster and mortar samples were observed to be mainly white with tints of grey and beige. Occasional white lumps were spotted scattered throughout the binder matrix. Dark grey and beige colored aggregates were identified in all samples. In the cross sections of mortar samples SM1 (Fig. 1 a) and SM4 (Fig. 1 c), aggregates with reddish brown hues which are probably brick fragments were also encountered. The aggregates in the examined samples were generally observed to have rounded edges (Fig. 1).

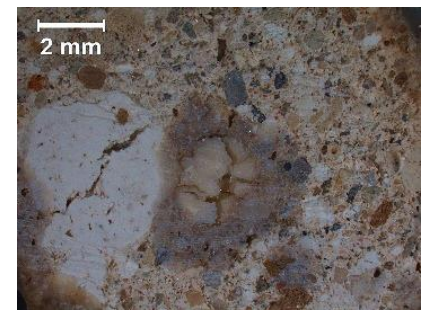

a

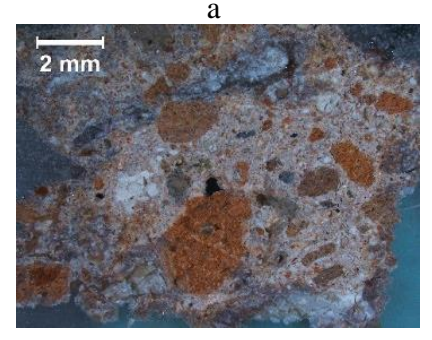

c

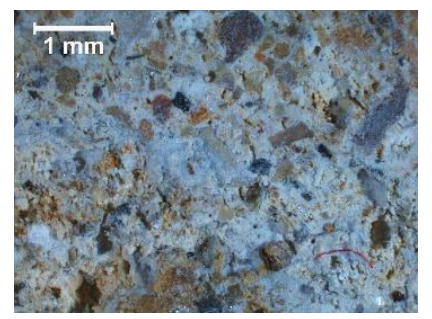

b

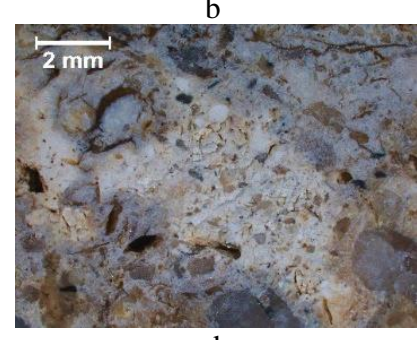

d
Fig. 1. General views of some representative mortar and plaster samples: a-SM1; b-SM3; c-SM4; d-SP1

Cohesion of the mortar and plaster samples appeared to be high [10].

Samples were found to have relatively low density and high effective porosity in line with data in related literature [16-18]. Bulk densities of the mortar samples were determined to vary between $1.04 \mathrm{~g} / \mathrm{cm}^{3}$ and $1.19 \mathrm{~g} / \mathrm{cm}^{3}$ while bulk densities of the plaster samples were in the range of $1.19-1.21 \mathrm{~g} / \mathrm{cm}^{3}$. Effective porosity values of the mortar and plaster samples were determined to be between $41-48 \%$ and $40-41 \%$, respectively (Table 2 ).

Although mortar samples appeared to be sound and resistant to crumbling, UCS test results could only be obtained for samples SM2 and SM4. Samples SM1 and SM3 failed in the tests before any reading could be taken. UCS values for the samples SM2 and SM4 found to be 3.92 and $4.47 \mathrm{MPa}$, respectively which are relatively low compared to contemporary cement mortars but sufficient for their intended purposes. Modulus of elasticity of the samples estimated by using bulk density values and results of ultrasonic pulse velocity measurements varied between 2.34-2.59 GPa for the plaster samples and 1.20$1.94 \mathrm{GPa}$ for the mortar samples (Table 2).

Table 2. Basic physical and physico-mechanical properties of samples

\begin{tabular}{|c|c|c|c|c|}
\hline Sample & $\begin{array}{c}\text { Bulk density, } \\
\mathrm{g} / \mathrm{cm}^{3}\end{array}$ & $\begin{array}{c}\text { Ef. porosity, } \\
\%\end{array}$ & $\begin{array}{c}\text { UCS, } \\
\mathrm{MPa}\end{array}$ & $\begin{array}{c}\mathrm{E}, \\
\mathrm{GPa}\end{array}$ \\
\hline SP1 & 1.21 & 40 & - & 2.34 \\
\hline SP2 & 1.19 & 41 & - & 2.59 \\
\hline SM1 & 1.04 & 48 & $\mathrm{n} / \mathrm{a}$ & 1.20 \\
\hline SM2 & 1.09 & 44 & 3.92 & 1.31 \\
\hline SM3 & 1.19 & 42 & $\mathrm{n} / \mathrm{a}$ & 1.82 \\
\hline SM4 & 1.12 & 42 & 4.47 & 1.94 \\
\hline
\end{tabular}

The percentages of acid soluble and insoluble parts of mortars and plasters were calculated after treating the samples with a dilute solution of hydrochloric acid. The results are given in graphical form in Fig. 2. Acid soluble parts were observed to vary between $48-90 \%$ for mortar samples and 80-84\% for plaster samples. The high percentage of acid soluble parts for mortar samples indicated the use of calcareous aggregates at high percentages in the mortar mixes except sample SM4 which was found to have acid insoluble aggregates at a percentage of $52 \%$.

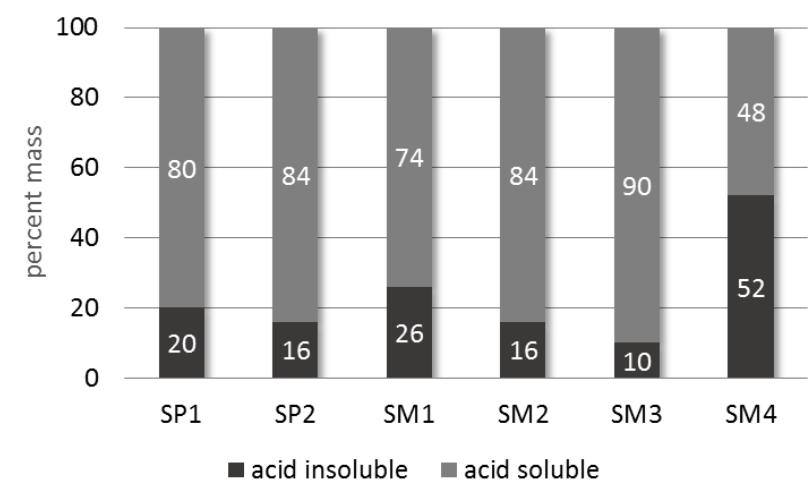

Fig. 2. Percentages of acid insoluble and soluble parts of the examined mortar and plaster samples

The particle size distribution of the acid insoluble parts of the samples showed that finer aggregates smaller than $125 \mu \mathrm{m}$ constitute $27-35 \%$ of the total acid insoluble part 
for mortars and $11-17 \%$ for plasters.

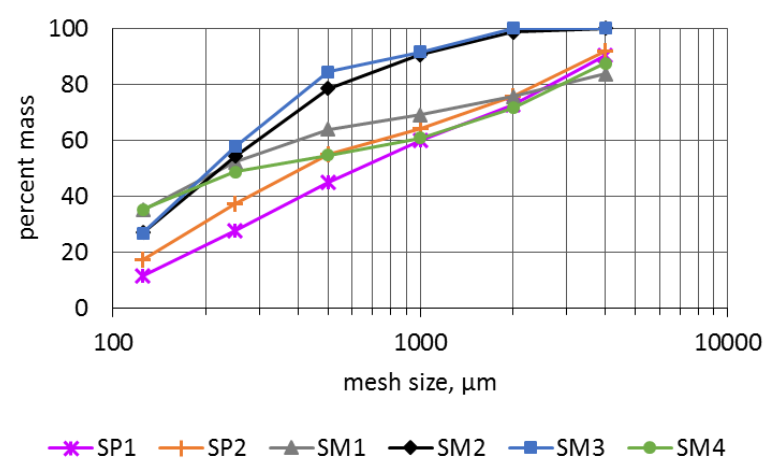

Fig. 3. Particle size distribution (cumulative) of acid insoluble parts of mortars and plasters

Similar percentages of the finer aggregates in relation to the total acid insoluble aggregates in different samples indicated the possibility that they were purposely added in mortar and plaster mixes as pozzolanic additives during their preparation. These finer aggregates of mortar and plaster samples were tested for their pozzolanic activity by measuring the electrical conductivity of the saturated $\mathrm{Ca}(\mathrm{OH})_{2}$ solution before and after mixing the solution with the aggregates. According to the classification of Luxan et. al., if the variation in conductivity is greater than $1.2 \mathrm{mS} / \mathrm{cm}$, the material can be classified as a good pozzolan [12]. The results of the pozzolanic activity tests for the finer aggregates of the examined mortar and plaster samples showed that the change in electrical conductivity is at least $3.1 \mathrm{mS} / \mathrm{cm}$ and up to $5.7 \mathrm{mS} / \mathrm{cm}$ showing that the aggregates $(<125 \mu \mathrm{m})$ of all mortar and plaster samples are highly pozzolanic confirming their careful selection and deliberate addition.

Table 3. Results of pozzolanic activity tests for the finer aggregates $(<125 \mu \mathrm{m})$ of mortar and plaster samples

\begin{tabular}{|c|c|}
\hline Sample & Pozzolanic activity, $\Delta \mathrm{mS} / \mathrm{cm}$ \\
\hline SP1 & 3.4 \\
\hline SP2 & 3.1 \\
\hline SM1 & 3.8 \\
\hline SM2 & 3.6 \\
\hline SM3 & 4.4 \\
\hline SM4 & 5.7 \\
\hline
\end{tabular}

The results of XRPD analysis of mortars and plasters revealed that calcite and quartz are the main mineral phases in all of the samples. Since calcite peaks from the binder and quartz peaks from the aggregates dominate the spectra of the samples, the intensity of other components were observed to be relatively low. Pozzolanic reaction products could not be observed in the XRPD spectra. For the samples SM3 and SM4, illite and albite peaks were clearly identified other than calcite and quartz. In the XRPD spectra of the samples SM1 and SM2, magnetite peaks were also detected with low intensities. The presence of magnetite in these samples were later confirmed by separating the magnetite from the acid insoluble parts of the aggregates belonging to SM1 and SM2 with the use of a magnet and performing XRPD analysis on the collected magnetic particles (Table 4).

Occasional white lumps encountered in the binder matrix of the samples which were probably consist of unmixed lime introduced to the mixes during the preparation of mortars and plasters were analyzed separately by XRPD and SEM-EDX analyses to determine the nature of the lime used (Fig. 4).

Table 4. Mineral phases detected in the mortar and plaster samples by XRPD analyses

\begin{tabular}{|c|c|}
\hline Samples & Mineral phases \\
\hline SP1 & calcite, quartz \\
\hline SP2 & calcite, quartz \\
\hline SM1 & calcite, quartz, magnetite \\
\hline SM2 & calcite, quartz, magnetite \\
\hline SM3 & calcite, quartz, albite, illite \\
\hline SM4 & calcite, quartz, albite, illite \\
\hline
\end{tabular}
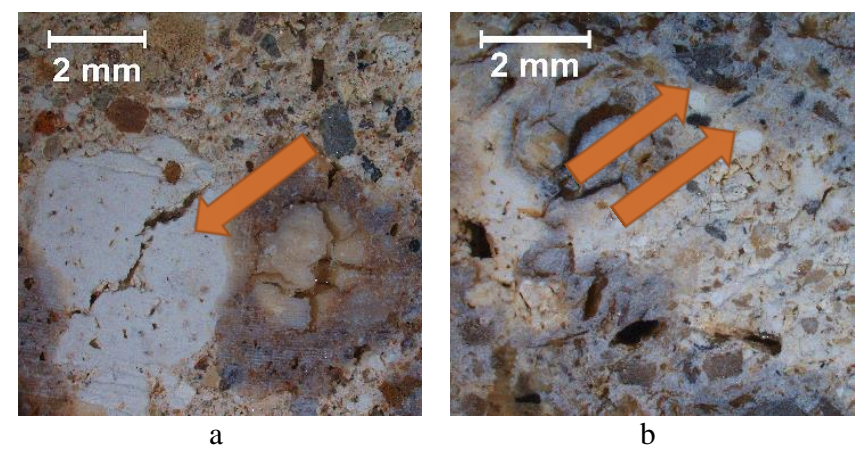

Fig. 4. Examples of white lumps encountered in the binder matrix of mortars and plasters: $a-S M 1 ; b-S P 2$

The results of XRPD analysis of the white lumps showed that they consist of pure calcite indicating the use of fat lime for the preparation of the mortars and plasters.

SEM-EDX analysis of the white lumps further confirmed that the binder used in the examined samples were pure lime (Fig. 5).

To identify the possible pozzolanic reaction products to be formed by the reaction of the finer aggregates with lime, the aggregates (pozzolanicity of which were confirmed to be high) were left in a saturated solution of $\mathrm{Ca}(\mathrm{OH})_{2}$ for 7 days and examined by SEM-EDX and FTIR analyses.

Visual examination of the aggregates, which were in powder form before the treatment, showed that aggregates were conglomerated and formed a solid disc after 7 days of immersion in the saturated $\mathrm{Ca}(\mathrm{OH})_{2}$ solution.

The SEM image in Fig. 6 a shows the granularity of the fine aggregates of sample SM3 before introduction to the saturated $\mathrm{Ca}(\mathrm{OH})_{2}$ solution. EDX analysis of the aggregates revealed the presence of silicium, aluminum, potassium and iron, however no calcium was detected (Fig. 6 b). The SEM image of the same aggregates after treatment with saturated $\mathrm{Ca}(\mathrm{OH})_{2}$ were appeared to have a different texture in which the granules are no longer visible (Fig. 6 c). Also in the EDX spectrum, calcium peaks were observed in addition to the peaks of previously detected elements (Fig. 6 d).

Since the solid disc of fine aggregates were thoroughly washed with distilled water before SEM-EDX analysis in order to remove any residual calcium ion not reacted with the aggregates, calcium peaks that were observed in the EDX spectrum belong to calcium that had reacted with the 
aggregates to form the pozzolanic reaction products.

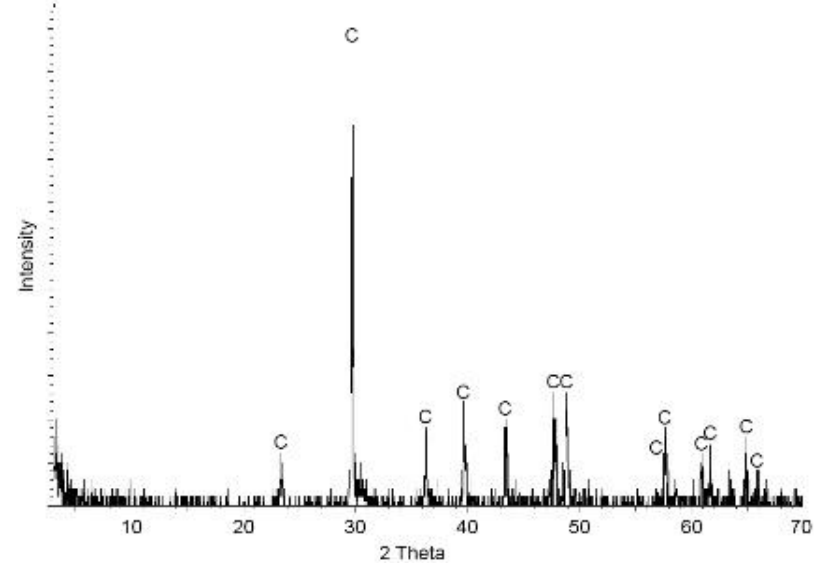

a
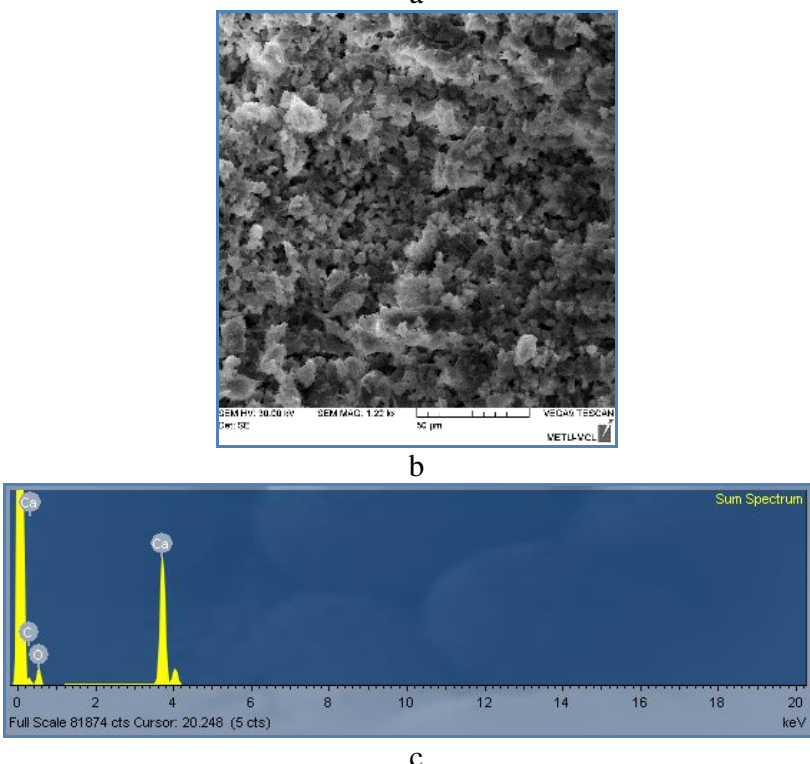

Fig. 5. Example for the a-XRPD spectrum; b-SEM image; c-result of EDX analysis of a white lump (sample SM1), $\mathrm{C}$ denotes calcite in the XRPD spectrum

In the FTIR spectra of the discs, a characteristic set of bands centered at around $970 \mathrm{~cm}^{-1}$ belonging to silicate vibrations of C-S-H due to Si-O stretching $[19,20]$ similar to tobermorite were observed. Also the band at $670 \mathrm{~cm}^{-1}$ with a relatively weaker intensity due to $\mathrm{Si}-\mathrm{O}-\mathrm{Si}$ bending [20] resembling those of tobermorite can be seen in the FTIR spectra confirming the formation of end products regarding to pozzolanic reactions.

Although the pozzolanic reaction products could not be identified in the XRPD spectra of the mortar and plaster samples because of their relatively weaker contribution to the spectra compared to the higher intensity peaks of calcite and quartz, the combined interpretation of the results indicated that fine aggregates with high pozzolanicity were used consciously in the investigated mortars and plasters to enhance the final characteristics and produce mortars and plasters with hydraulic properties.

\section{CONCLUSIONS}

Mortar and plaster samples of the Byzantine Church in the study were assessed to be prepared using fat lime with deliberate addition of finer aggregates with good pozzolanicity in consistent proportions.

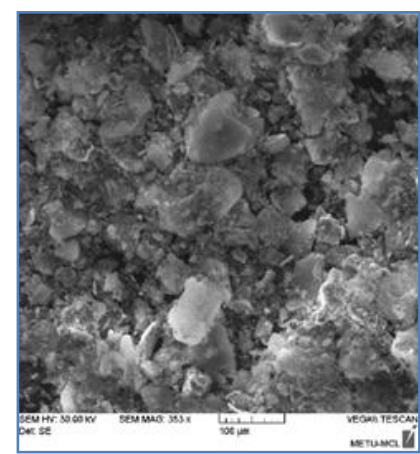

a

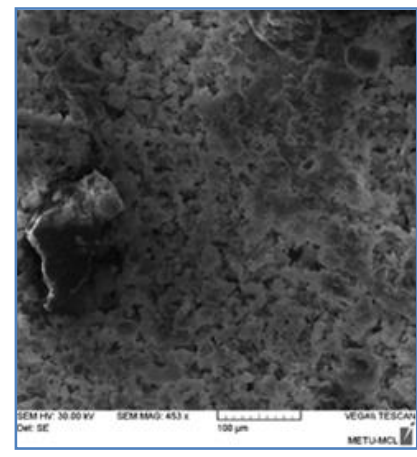

$\mathrm{c}$

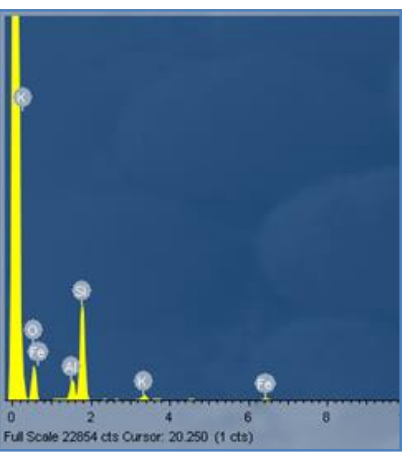

b

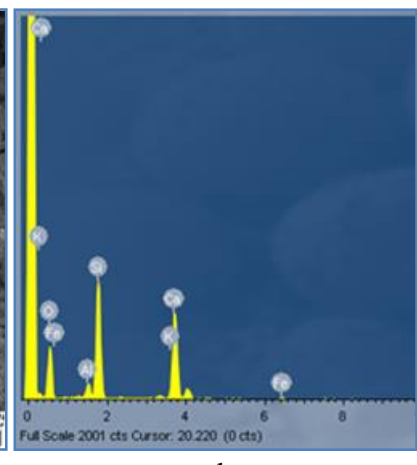

d
Fig. 6. SEM image and EDX analysis of fine aggregates (SM3) before $(a, b)$ and after $(c, d)$ reaction with $\mathrm{Ca}(\mathrm{OH})_{2}$

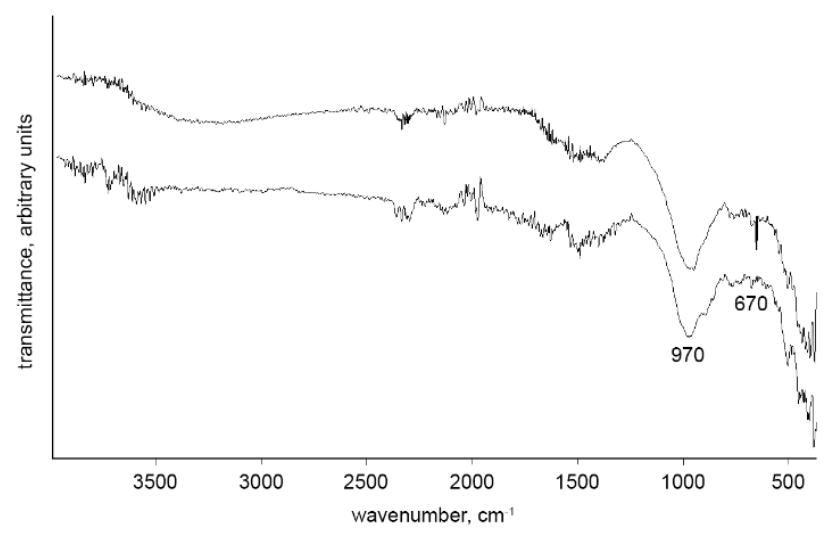

Fig. 7. FTIR spectra of fine aggregates of SM3 (above) and SM4 (below) after reaction with $\mathrm{Ca}(\mathrm{OH})_{2}$

Mortar and plaster samples were observed to have relatively low bulk density and high porosity values which is usually the case for historical lime mortars and plasters. Mechanical strength values of the mortars were in the range of 3.92 and $4.47 \mathrm{MPa}$ which appeared to be relatively low but sufficient for their intended purposes. Mortars or plasters with much higher compressive strength or having physical/physico-mechanical properties that differ substantially from the original materials should not be used for the repair works of historic structures considering the crucial priority of material compatibility. In addition, materials that may introduce deterioration problems related with chemical incompatibility should also be avoided. Long time durability of pozzolanic lime mortars and plasters in time shows that these composite materials are efficient for their use cases in historical 
structures. As in the case of this particular structure, lime mortars and plasters with pozzolanic additives can be considered as appropriate repair materials, however physical, physico-mechanical and microstructural characteristics of the repair mortar and plaster mixes to be proposed should be examined after curing so that the compatibility with the original materials in terms of essential parameters is ensured.

\section{Acknowledgments}

The authors thank to Prof. Dr. Bilal Söğüt, Director of Stratonikeia Excavation for providing the mortar and plaster samples.

\section{REFERENCES}

1. Moropoulou, A., Bakolas, A., Bisbikou, K. Investigation of the Technology of Historic Mortars Journal of Cultural Heritage 1 2000: pp. 45-58. https://doi.org/10.1016/S1296-2074(99)00118-1

2. Odgers, D., Henry, A. Practical Building Conservation Stone by English Heritage. Ashgate Publishing Limited, Farnham, 2012.

3. Knight, J. The Repair of Historic Buildings in Scotland; Advice on the Principles and Methods. Historic Scotland, Edinburgh, 1995.

4. Binda, L., Baronio, G., Tiraboschi, C., Tedeschi, C. Experimental Research for the Choice of Adequate Materials for the Reconstruction of the Cathedral of Noto Construction of Building Materials 17 2003: pp.629-639. https://doi.org/10.1016/S0950-0618(03)00059-X

5. Velosa, A.L., Coroado, J., Veiga, M.R., Rocha, F. Characterization of Roman Mortars from Conímbriga with Respect to their Repair Material Characterization 58 2007: pp. $1208-1216$. https://doi.org/10.1016/j.matchar.2007.06.017

6. Papayianni, I. Design of Compatible Repair Materials for the Restoration of Monuments International Journal for Restoration 10 (6) 2004: pp. 623-636. https://doi.org/10.1515/rbm-2004-5902

7. Papayianni, I., Stefanidou, M. Mortars for Intervention in Monuments and Historical Buildings. In: Brebbia, C.A. (Ed.), Proceedings of Studies, Repairs and Maintenance of Heritage Architecture VIII, Greece, 2003: pp. 57-64.

8. Söğüt, B. Stratonikeia 2012 Yılı Çalışmaları. 35. Kazı Sonuçları Toplantıs1, T.C. Kültür ve Turizm Bakanlığı Kültür Varlıkları ve Müzeler Genel Müdürlüğü, Muğla, 2014: pp. $448-464$.

9. Söğüt, B. Stratonikeia'da Hellenistik Dönem Öncesi. In: Tekocak M. (Ed.), K. Levent Zoroğlu'na Armağan. Suna-
İnan Kıraç Akdeniz Medeniyetleri Araştırma Enstitüsü, İstanbul, 2013: pp. $605-623$.

10. Normal, 12/83, 1983, Aggregati Artificiali di Clasti a Matrice Legante non Argillosa: Schema di Descrizione. CNR-ICR, Roma.

11. RILEM TC 25-PEM, Recommended Tests to Measure the Deterioration of Stone and to Assess the Effectiveness of Treatment Methods Materials and Structures $13(73)$ 1980: pp. $173-253$.

12. ASTM Standard D2845, 2000, Standard Test Method for Laboratory Determination of Pulse Velocities and Ultrasonic Elastic Constants of Rock. ASTM International, West Conshohocken, PA.

13. Brook, N. The Equivalent Core Diameter Method of Size and Shape Correction in Point Load Testing International Journal of Rock Mechanics and Mining Sciences \& Geomechanics Abstracts 22 (2) 1985: pp. 61-70. https://doi.org/10.1016/0148-9062(85)92328-9

14. ASTM Standard D5731, 2016, Standard Test Method for Determination of the Point Load Strength Index of Rock. ASTM International, West Conshohocken, PA.

15. Luxan, M.P., Madruga, F., Saavedra, J. Rapid Evaluation of Pozzolanic Activity of Natural Products by Conductivity Measurement Cement and Concrete Research 19 (1) 1989: pp. $63-89$. https://doi.org/10.1016/0008-8846(89)90066-5

16. Tunçoku, S.S., Caner-Saltık, E.N. Opal-A Rich Additives Used in Ancient Lime Mortars Cement and Concrete Research 36 (10) 2006: pp. 1886-1893. https://doi.org/10.1016/j.cemconres.2006.06.012

17. Borges, C., Santos Silva, A., Veiga, R. Durability of Ancient Lime Mortars in Humid Environment Construction and Building Materials 66 2014: pp. 606-620. https://doi.org/10.1016/j.conbuildmat.2014.05.019

18. Franzini, M., Leoni, L., Lezzerini, M. A Procedure for Determining the Chemical Composition of Binder and Aggregate in Ancient Mortars: Its Application to Mortars from Some Medieval Buildings in Pisa Journal of Cultural Heritage 1 (4) 2000: pp. 365-373. https://doi.org/10.1016/S1296-2074(00)01092-X

19. Thirumalini, S., Ravi, R., Sekar, S.K., Nambirajan, M. Knowing from the Past - Ingredients and Technology of Ancient Mortar Used in Vadakumnathan Temple, Tirussur, Kerala, India Journal of Building Engineering 4 2015: pp. $101-112$. https://doi.org/10.1016/j.jobe.2015.09.004

20. Yu, P., Kirkpatrick, R.J., Poe, B., McMillan, P.F., Cong, X. Structure of Calcium Silicate Hydrate (C-S-H): Near-, Mid-, and Far-Infrared Spectroscopy Journal of the American Ceramic Society 82 1999: pp. 742-748. https://doi.org/10.1111/j.1151-2916.1999.tb01826.x 